\title{
Seeking children's perspectives: a respectful layered research approach
}

\author{
Jane Merewether
}

School of Education, Curtin University, Perth, Australia

\author{
Alma Fleet \\ Institute of Early Childhood, Macquarie University, Sydney, Australia.
}

Jane Merewether (corresponding author)

Curtin University, School of Education, Bentley WA 6845

+61892662254

j.merewether@curtin.edu.au

\author{
Alma Fleet \\ Macquarie University, Institute of Early Childhood, North Ryde NSW 2109 \\ +61298509872 \\ alma.fleet@mq.edu.au
}

Jane Merewether is a lecturer at the School of Education at Curtin University, Australia, and is a $\mathrm{PhD}$ candidate at Macquarie University, Australia. Her research focus is early childhood settings as places of democratic participation.

Alma Fleet, PhD, Associate Professor, works at the Institute of Early Childhood, Macquarie University, Australia. Her research interests include the nature of teachers' work and processes of educational change. 


\section{Seeking children's perspectives: a respectful layered approach}

This article discusses why researchers and educators might choose to seek children's perspectives. It also highlights some of the key considerations when seeing children as having the right to contribute to decisions that affect them. The article draws on findings from a study that used pedagogically oriented methods for researching threeand four- year old children's perspectives about outdoor spaces in the early childhood setting they attended. The article discusses the possibilities and practicalities of this research approach for both research and for pedagogy. Examples are provided for others who may be considering working/researching in these ways.

Keywords: participatory research; Mosaic approach; children's perspectives; listening as method, young children's environments;

\section{Introduction}

This article draws on findings from a study (Merewether, 2012) that investigated three- and four- year old children's perspectives about outdoor spaces in the Western Australian early childhood setting ${ }^{1}$ they attended. The paper describes and advocates for methods used in this study with the hope that these accounts may be useful to others wishing to making children's voices visible in research or pedagogy. The project was a collaboration between two researchers, one with a long history as an early childhood academic and the other with a long history as an early childhood teacher. Investigating possibilities for making children's voices visible has characterised the work of both authors (for example: Fleet \& Britt, 2011; Fleet, Patterson, \& Robertson, 2006, 2012; Merewether, 2007a; Merewether, 2007b, 2012) who are also interested in finding ways to go beyond the theory/practice divide (Lenz Taguchi, 2009) to explore intersections between research and pedagogical approaches.

The paper begins by discussing influences that may lead researchers and educators to consider seeking children's perspectives. It then details the methodological approaches used

\footnotetext{
${ }^{1}$ In the Australian context, early childhood 'settings' refer to educational and care programmes that children, usually under five-years-old, attend outside the home. These programmes may be administered by schools, not-for-profit organisations, or private businesses.
} 
in the study and discusses the unfolding research project. The article concludes with some reflections on the study as a whole, including implications for similar studies.

\section{Changing perspectives}

In much research about children, they 'have been the invisible and voiceless objects of concern, and not understood as competent, autonomous persons who have a point of view' (Smith \& Taylor, 2000, p. ix). The field of developmental psychology, with its emphasis on universal stages of development, socialisation, and a view of children as 'objects' to be studied, has dominated the way that children and childhood have been constructed (Dahlberg, Moss, \& Pence, 2007; Mayall, 2002; Woodhead \& Faulkner, 2008). Researchers, reflecting these dominant constructions, have subsequently tended not to have had a culture of listening to young children and have neglected their perspectives (Clark, 2005; Lansdown, 2005; Smith, 2011). This has been changing, however, and over the last two decades, rather than seeing children from a perspective of 'needs', researchers are now more commonly viewing children as knowledgeable and competent members of society who are capable constructors of their own knowledge (Bruner, 1996; Dahlberg et al., 2007; Rinaldi, 2006).

Theoretical perspectives associated with socioculturalism (Rogoff, 2003; Vygotsky, 1978) have made a major contribution to changing images of children. Sociocultural theory draws attention to the role of social context and social meaning in learning and suggests that children, from birth, construct their understandings in partnership with others, both adults and children. Sociocultural perspectives have in turn informed another influential theoretical paradigm, the field of Childhood Studies (Corsaro, 1997; James, Jenks, \& Prout, 1998; James \& Prout, 1990; Mayall, 2002; Qvortrup, Corsaro, \& Honig, 2009). Childhood Studies, which draws on a range of disciplines including sociology, anthropology, psychology, history, and geography, has highlighted the ways early childhood is constructed and reconstructed, not only for children, but also by children (James \& Prout, 1990). As Smith (2011, p. 15) points out, a major contribution of Childhood Studies has been, 'to recognize children's agency, and to emphasise that children are not just empty vessels whose development is determined by biological and psychological processes.' Sociocultural and Childhood Studies perspectives vary in their orientation and emphases, but are united by their rejection of an image of children as products of socialisation or development, and instead position children as social actors capable of holding opinions and ideas.

Another contributor to the changing image of children is the United Nations Convention on the Rights of the Child (henceforth referred to as the Convention) (United 
Nations, 1989), which made a commitment to recognise children as active citizens with rights to participate in matters affecting them, including research. Article 12 of the Convention declares, 'States Parties shall assure to the child who is capable of forming his or her own views the right to express those views freely in all matters affecting the child...' (United Nations, 1989). In 2005, General Comment 7 (United Nations, 2005, p. 3) specifically reiterated Article 12 applies also to younger children:

The Convention requires that children, including the very youngest children, be respected as persons in their own right. Young children should be recognised as active members of families, communities and societies, with their own concerns, interests and points of view.

There are some indications that these perspectives are influencing governments and other decision makers. In Australia, for example, the nationally mandated Early Years Learning Framework (Australian Government Department of Education Employment and Workplace Relations (AGDEEWR), 2009) makes an explicit link to the Convention, noting in particular, its recognition of children's right to be 'active participants in all matters affecting their lives' (p. 5). Some government resources and accreditation requirements have encouraged educators to involve children in decision making, for example: Caterpillar Toothpaste: A Child's Introduction to the Decision Making Process (Lander, Tennant, \& Webb, 2005), and Factsheet 2: Involving Children in Decision Making (National Childcare Accreditation Council Inc, 2005).

Notwithstanding these contributions, it would appear that on the whole, Australian early childhood policy is yet to reflect images of young children as having rights to, and being capable of democratic participation in their daily lives (Ailwood et al., 2011; Mac Naughton, Hughes, \& Smith, 2007). Similarly, in England, analysis of the inclusion of children's voices noted 'a slow but growing acknowledgement of the centrality of the rights of children as citizens' (Pascal \& Bertram, 2009, p. 252), but ultimately, 'In many settings these hard fought for rights of children are not yet evident in practice. The same is true for much early childhood research, where children's continued lack of voice and power persists' (Pascal \& Bertram, 2009, p. 253). Seemingly, while there are moves in some spheres to include children's voices, translation into research and pedagogical practice is still evolving.

\section{The experience of Reggio Emilia}


One of the reasons for the lack of translation into practice is that methodologies and methods for such research are still experimental (Gallacher \& Gallagher, 2008). One exception, however, is the educational project of Reggio Emilia (Edwards, Gandini, \& Forman, 2012b; Giudici, Rinaldi, \& Krechevsky, 2001; Rinaldi, 2006), which successfully makes children's voices visible and therefore offers possibilities for researchers who wish to work with children and educators in a collaborative and participatory manner. This community-based approach to education for children aged from birth to six has been evolving for over 50 years and has become internationally influential (Edwards, Gandini, \& Forman, 2012a). The project, with its emphasis on children and adults working together with an 'attitude of research' (Rinaldi, 2006, p. 101) meticulously recorded using pedagogical documentation (Dahlberg et al., 2007; Edwards et al., 2012b; Fleet et al., 2006, 2012; Giudici et al., 2001), has graphically made visible the capabilities of young children.

One of the fundamental ideas of the educational project of Reggio Emilia is the 'pedagogy of listening' (Rinaldi, 2006, pp. 65-68). This pedagogy (Rinaldi, 2006) involves: Using all of the senses to listen with intent, curiosity and sensitivity; interpretation and giving meaning; being open to differences, suspending judgments and being open to change; and, understanding that rather than producing answers, listening will generate more questions. In addition, a pedagogy of listening also includes:

- 'multiple listening' (p. 67), involving children's and adults' voices;

- 'interior listening' (p. 65), involving individual representation of knowledge in a group context; and

- 'visible listening' (p.68), which is documentation of the listening (such as photos, and notes) to make visible children's and adults' theories, ideas and processes.

Another key idea from Reggio Emilia is the theory of 'the hundred languages of children' (Edwards et al., 2012b), a metaphor for the 'the different ways children (human beings) represent, communicate and express their thinking in different media and symbolic systems' (Vecchi, 2010, p. 9). This includes verbal language forms, but also drawing, painting, music, dance, drama, clay and wire, to name a few.

The hundred languages of children, together with the pedagogy of listening, have informed researchers seeking to include children's perspectives in their work (Clark \& Moss, 2001; Einarsdottir, 2005; Fleet \& Britt, 2011; Harcourt, 2011). Clark \& Moss (2001) developed what they called a 'Mosaic approach' to create a 'composite picture or "mosaic" 
of children's lives' (Clark, 2010b, p. 117) by piecing together findings from observations, child-led tours, conversations, children's photography and drawings. Taking an eclectic approach to data generation enables children in the early stages of language development a variety of possibilities, verbal and non-verbal, to describe their environment. Therefore, our study used Mosaic approach-inspired methods to seek three- and four- year-old children's perspectives regarding outdoor spaces at the early childhood setting they attended. Our experiences with these methods will now be discussed.

\section{Deconstructing the approach: layers of intentional decision-making}

The research used a case study design as case studies offer researchers opportunities to study a single example in-depth (Merriam, 1998). Key elements can be highlighted as characterising the layered approach used in this study, beginning with the participants.

\section{Choosing participants; gaining consent}

Site selection was criterion-based (LeCompte, Preissle, \& Tesch, 1993, p. 69) using the following criteria: The setting

- was considering making changes to its outdoor spaces.

- valued outdoor learning as an integral part of the curriculum.

- had at least one educator of children between three and five years old who was supportive of the collaborative research approach.

- was conveniently located to enable frequent visits to the site.

Colleagues with knowledge of the early childhood sector were asked to suggest a setting that met these criteria. An early childhood setting situated in suburban Perth, Western Australia, which included two classrooms each welcoming 25 three- and fouryear olds and sharing one outdoor space, was selected.

Having chosen the prospective site, $\mathrm{I}^{2}$ (Jane) spoke by phone with the director, explaining the research aims and procedures. Once the director's approval was obtained, I met with her and the two educators from each class to explain the project and their potential involvement. The director and educators were key crucial mediators in the process of gaining consent from parents so it was important they had a clear understanding of the study's

\footnotetext{
${ }^{2}$ As Jane conducted the fieldwork, the pronouns 'I' and 'me' describe Jane's experiences in the setting.
} 
purpose and methods. In consultation with the educators, eight children, four boys and four girls, were chosen as key informants. This group was selected to include a mix of interests, ethnicities, and perceived abilities, and consisted of five three-year-olds, and three four-yearolds. Three of the group came from homes where a language other than English was spoken. It was also important to select children who were comfortable talking with a stranger and demonstrated willingness to articulate or draw their points-of-view.

Although data generation focussed on the subset of children, consent was sought from all parents in both classrooms. This was done to reduce situations where data that included children outside the subset group would be unusable due to lack of parental consent, for example, if one of the children from the selected group photographed a child outside the subset. The educators handed a combined information/consent letter to all parents and answered parents' queries, or invited them to phone me. Two parents did not provide consent; their reasons are unknown.

\section{The study}

Children vary in their abilities, experiences, and preferences. A key feature of this study was providing children with a choice of ways they could participate to enable them to have opportunities to express their thoughts using ways in which they were comfortable. This was not always convenient for us as researchers, particularly when children exercised their right not to participate; however, we believe that limiting children's means of expression would have detracted from the integrity of the data by increasing the likelihood of responses provided to please the adult rather than representing genuine thinking.

The study took place over eight weeks. Having gained parental consent, the site was visited each week for at least half a day, with some longer visits. Figure 1 details the focus of each weekly visit. 
Figure 1 Study stages
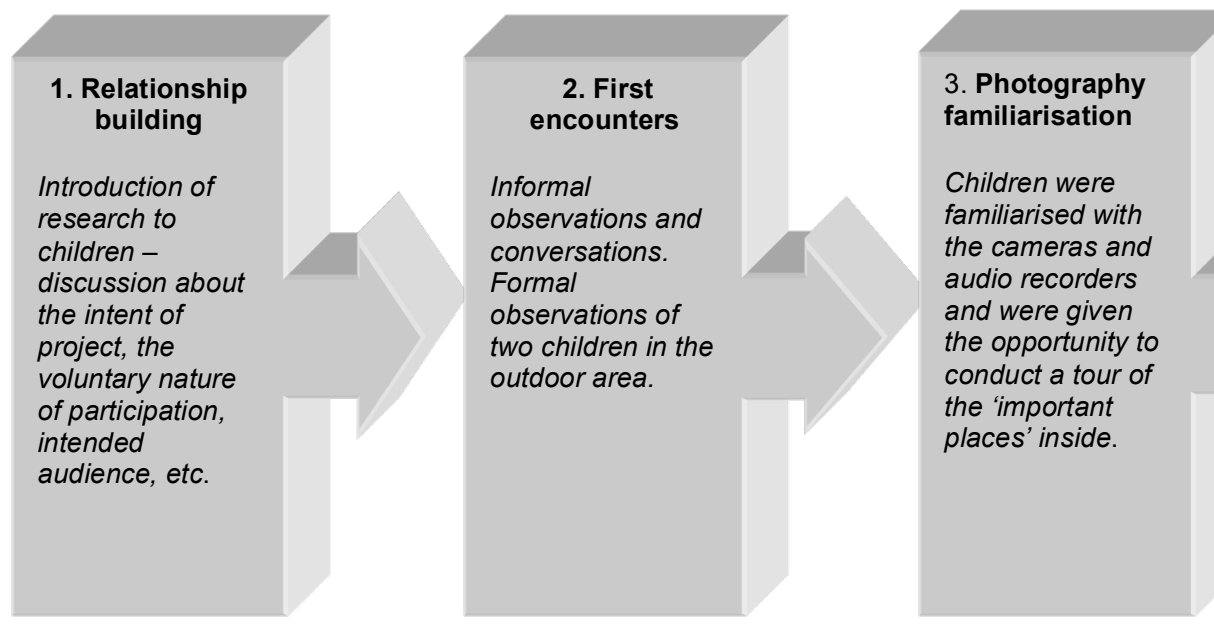

4. Child-led tours

Children took researcher on a tour of outdoor area, photographing 'important linteresting /special places.'

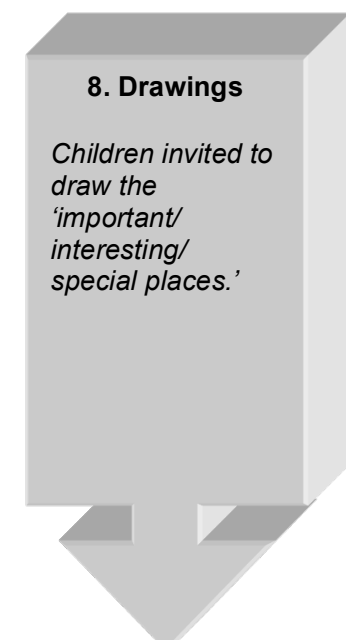

7. Slide show
Photo-elicitation
focus group
based on
emerging
themes.

Setting makes decisions for outdoor area, informed by children's perspectives.

\section{Beginning the visits: relationship building}

The study began with a visit to the setting to introduce myself and explain the research to the children. I took care to ensure that they understood the various terms; for example, the word 'research' was discussed and equated with 'finding out' and 'discovering'. I emphasised the voluntary nature of participation, as well as the option to withdraw at any time without consequences. I explained that only some children would be working with me each time I visited; educators were asked to conduct similar activities with other children who wished to 
participate as part of the regular program. Materials and equipment were provided to the educators for this purpose; for instance, I left a camera with the educators so children who wanted to take photos of important places in the outdoor space could do so.

During the first visit, I spent several hours chatting with the children who involved me in their play, asked me about myself, talked about what they were doing at the centre, told me about their families, and so on. These conversations were not recorded; rather, their role was to develop the children's confidence in me and to help me get to know them.

\section{Gaining the children's consent}

Ongoing consent, or 'assent' was sought from children throughout the project. The term assent is used here to distinguish between the formal one-off written consent sought from adults and the unwritten agreement to participate that was gained from children. Verbal assent was sought from children throughout the data generation process, not just at the beginning of each session. Having informed children about the research at the outset, they were repeatedly re-informed during the project and asked if they wanted to continue to participate. I also watched for any signs of non-verbal withdrawal of assent. For example, if children appeared to not be interested in a particular activity, then this was taken as a withdrawal of assent. Children were reminded frequently that they could leave the activity if they wanted to, which was an option exercised quite often. Although it did not occur, had children indirectly indicated they did not wish to participate in any aspect of the study, for example via educators or other children, this would also have been considered withdrawal of assent. Some researchers (Dockett, Perry, \& Kearney, 2012; Harcourt \& Conroy, 2005, 2011) have sought written consent from children but the decision was taken in this instance to rely on obtaining repeated verbal assent as it seemed to better reflect their everyday experience.

A challenge of undertaking research activities with children that are part of their everyday pedagogical experiences is the possibility that 'researchers are expressly taking advantage of children's schooled docility towards such activities' (Gallacher \& Gallagher, 2008, p. 506). In many aspects of their lives, children are required to 'do as they are told' by adults, therefore, I took particular care to repeatedly remind children and their educators that children are merely being offered invitations to participate. By doing this, we feel confident that in our study children's participation was not a result of their 'schooled docility', as they frequently exercised their right to withdraw assent, depending on their personal orientation towards each activity, and what else was happening at the time. 


\section{What about confidentiality?}

Because the study was about giving children a voice and there were to be no deficit constructions of children, parental consent was sought and obtained to use first names and photos of faces. This was particularly important, as the data were being constantly presented and re-presented to children, families, and educators in a documentation book (figure 5) that progressively told the story of the research. This book was kept at the centre in a prominent position accessible to children, educators and families and it would have defeated the purpose of the study to have had children's identities concealed. The continual re-presenting of data to children, families, and educators provided the option for them to change or remove it. Nonetheless, we were advised that the ethics committee would be more amenable to the use of pseudonyms in publications and presentations external to the setting. This was explained to the children who reacted with expressions of bemusement or, in the case of two children, indignation. They gave me the impression they saw my subsequent explanation as inadequate and I felt by disguising their names, I was betraying my commitment to them to make their ideas visible. Conroy and Harcourt (2009, p. 163) had a similar experience with children requesting that their real names be used as their 'real names say who they really are'. In future studies, we will be pursuing ways of avoiding the use of pseudonyms entirely.

\section{Considering power relations}

When adults work with children, there are going to be power imbalances. As Foucault says, 'Human relations, whatever they are - whether it be a question of communicating verbally or a question of a love relationship, an institutional or an economic relationship, power is always present' (Foucault, 1987, p. 11). In this study, we were acutely aware of the power imbalances that exist between adults and children and took a number of steps to minimise them. First among these was to place myself in the position of learner. The children were the knowledge holders and my responsibility was to listen and learn. Second, to give the children more confidence to participate in the research activities, they always worked with me in pairs or small groups. Each pair was friendship-based (as suggested by the educators); this also meant the children did not feel they were missing out on time with their friends while they were participating in the research. An added advantage of working with the children in groups was that it facilitated the social construction of knowledge as each child responded to the thoughts of others. For example, when describing places they thought important at the setting, one pair decided to photograph where they played a game about being shipwrecked: 
Levi: I'm going to take a picture of the storm things in here!

Charlie: Me too! I'm going to take a picture of the river starting getting rough!

Third, data generation took place in the children's spaces. Even though at times, from an adult perspective, it would have been easier to take children to, say, the director's office or the staffroom where there would have been fewer distractions, all research activities were conducted in children's spaces, most often outdoors.

\section{Participating and observing}

Observation is a major means of generating data in qualitative research (Merriam, 2009) and is an important starting point for listening to young children's perspectives (Anning \& Edwards, 2006; Clark \& Moss, 2001). Observations occurred throughout this study, forming part of the overall mosaic or picture. These observations were made by me as a participantobserver (Merriam, 2009). The study did not presume that the observations were neutral; on the contrary, the research was underpinned by an assumption that observation is not only a process, but also a subjective interpretation (Rinaldi, 2006), made in the light of individual point-of-views, theories and hypotheses. In addition, children and adults who know they are being observed are likely to behave in socially acceptable ways (Merriam, 2009) so I needed to be sensitive to the possible effects of this on data generation and interpretation. The continual re-presenting of data to the children provided opportunities for dialogue about the effects of my presence.

It was my aim to take a 'collaborative partner' (Merriam, 2009, p. 125) role in which the relationship between myself, the children and the educators was equal, although the line between being 'observer' and 'participant' shifted during the course of the study and inevitable power differentials were acknowledged. At the outset, my role leaned to that of observer, but as relationships developed over time, it leaned more to that of participant. As a participant, the children came to frequently request my assistance, invite me into their play, conversations, and activities. Thus, I began to take roles that might otherwise have been undertaken by the educators, such as helping children to negotiate minor differences of opinions, clean up spills, or assist with set activities. I ensured, however, that children remained aware that my primary role in the group was as researcher. 


\section{Using photography and audio-recording with children}

In the last decade or so, a number of researchers have used photographs taken by children for data generation (for example, Clark, 2005; Clark \& Moss, 2001; Dockett \& Perry, 2005; Einarsdottir, 2005; Fleet \& Britt, 2011; Loizou, 2011; Stephenson, 2009). Because they are in charge of the camera, child-led photography allows children freedom to make decisions about what will and will not be photographed (Einarsdottir, 2005). In addition, photography provides children who may not have strong verbal or written skills, with a non-verbal means of representing their ideas (Clark, 2005; Einarsdottir, 2005). Most importantly, researchers who have used child-led photography have found it has great appeal for young children (Clark, 2005; Clark \& Moss, 2001; Dockett \& Perry, 2005; Einarsdottir, 2005; Stephenson, 2009), which we also found. Digital cameras were used in our study for their relative inexpensiveness, ease of use, and low cost of processing. They also offered the possibility of immediate review of photos taken.

Some researchers (Agbenyega, 2011; Loizou, 2011) have used child-led photography in which children are not accompanied by the researcher as they take photos, but we decided to accompany the children, as several researchers (Clark \& Moss, 2001; Einarsdottir, 2005; Stephenson, 2009) have noted the richness of conversation that occurs while children are taking photos. With the children's permission, the conversation that took place was audiorecorded, and was included as observational data. Digital audio-recorders were suspended around children's necks on a lanyard. To assist with sound quality, inexpensive clip-on microphones were used; the resulting quality of the sound was excellent. Children were very enthusiastic about the audio-recorders, particularly in recording and playing back their own voices. Unfortunately, this made keeping track of data problematic, as the children recorded over conversations that had not been transcribed. I explained this problem to the children and asked if in future it would be possible for them to not press any buttons on the recorders; they seemed happy to comply with this request. In subsequent studies, to reduce the novelty factor of recording and hearing their own voices, we would consider giving children opportunities to use audio-recorders freely prior to the data generation sessions. The educators may be able to assist with such opportunities.

\section{Child-led tours}

On the third visit to the setting, as a way of familiarising children with the cameras and the research techniques, I presented the cameras to the children, explaining that they were expensive and somewhat fragile. I asked them to keep each camera's strap around their wrist, 
and showed how to frame, view, and take a photo. Several children indicated they had used digital cameras, including one who told me she had her own camera; she needed almost no instruction. Another child seemed quite unfamiliar with a digital camera, but she clearly knew something about cameras as she kept holding it up to her eye as if it had a viewfinder. Initially, this child took several photos of her own fingers as she held onto the camera with her hands on the lens. Nonetheless, within five minutes, she was competently taking photos of her surroundings.

As a familiarisation strategy, I invited pairs of children to show me, as an 'authentic novice' (Clark \& Moss, 2005, p. 97), and to record with photos the 'interesting/special/important' places in the indoor setting. Although they took a few photos where the framing was out, or that were blurred (even though the cameras were selffocusing), overall on this tour, the children proved themselves to be competent photographers who took deliberate, precise photos (figure 2).

Figure 2 Children's first photos

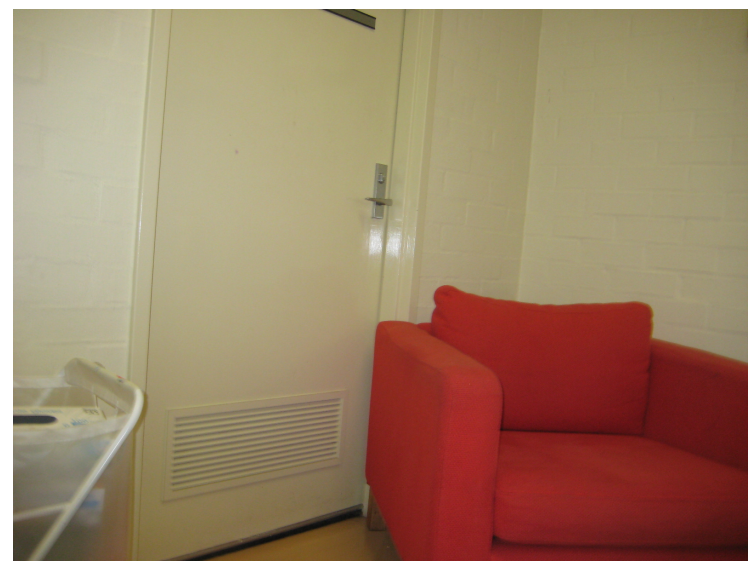

'The teacher's chair'

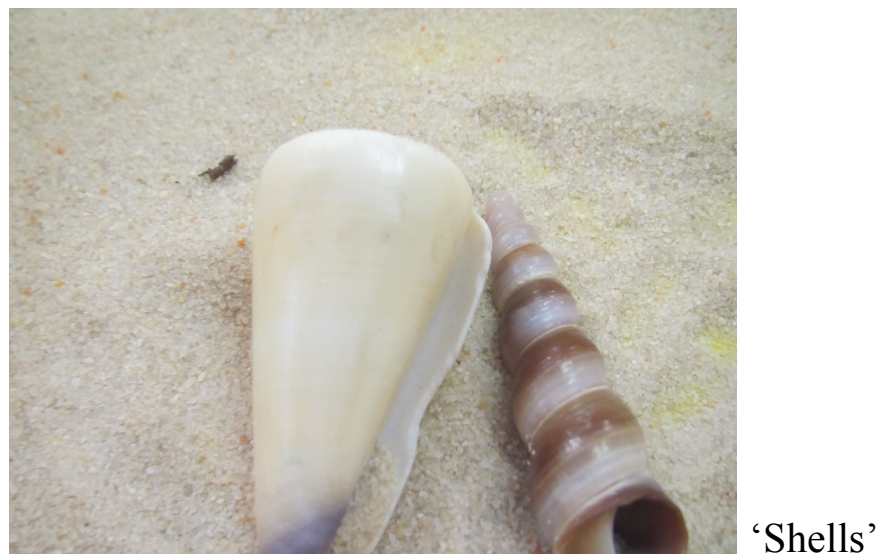


This first tour, however, revealed the importance of having conversations with the children about the photos they had taken. For instance, one photo appeared to me to be of a fluorescent light on the ceiling, but as the child pointed out, it was in fact a photo of me taken from a child's-eye-view: 'That's a photo of you and you're important' (figure 3). Because I am standing underneath a light in the photo, I am silhouetted and difficult to see, but the light is prominent.

Figure 3 'That's a photo of you and you're important'

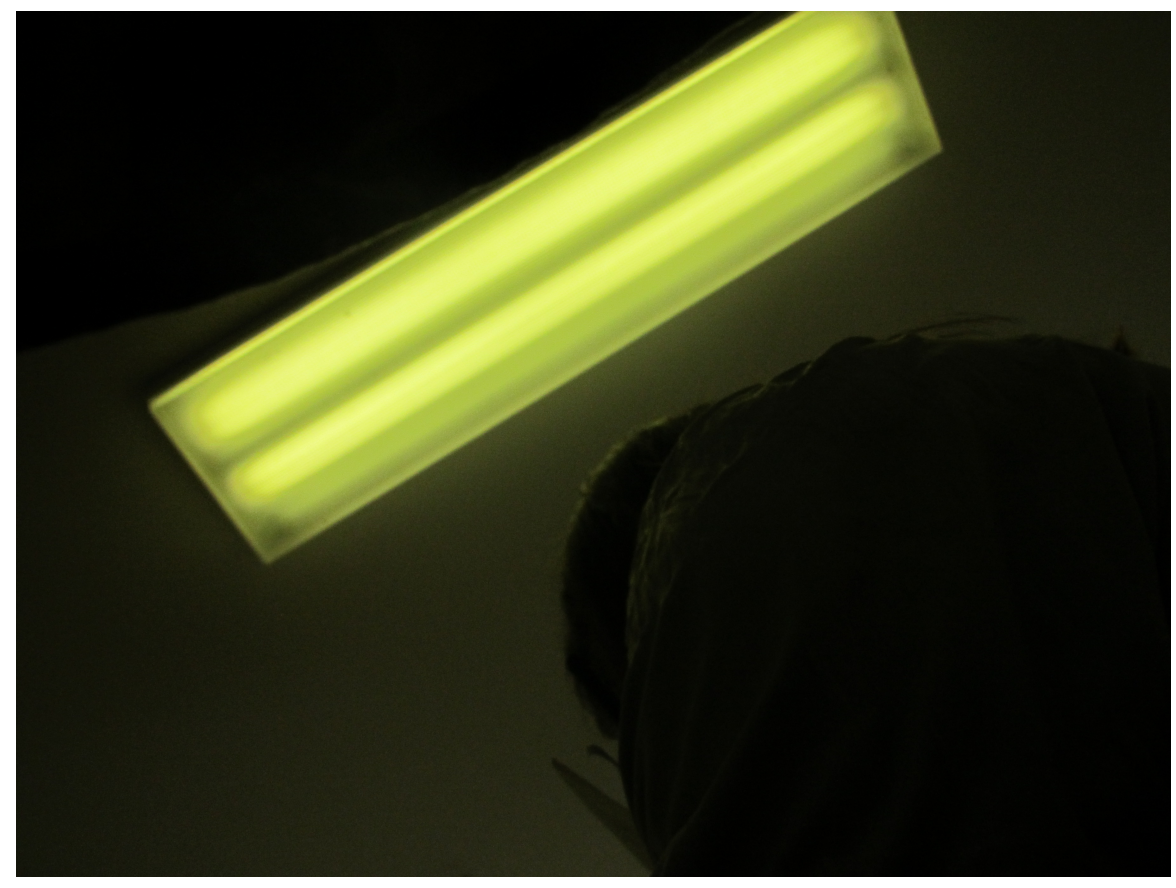

Another photo could have been interpreted as a photo of a flyscreen door; however, even though the children had been asked to take photos of important places indoors, the child told me this was a photo of the outdoors.

Electing to conduct indoor tours before conducting tours of outdoor areas turned out to be very advantageous. Not only did the indoor tours provide an authentic context for children to become familiar with the equipment and practice their photography skills, but these tours also provided a chance to discover potential challenges. For example, this is where I first encountered the previously discussed issues with the audio-recorders, and was also how I discovered that I needed to be explicit in asking pairs of children to take me on a 
tour 'together'. Otherwise there was a tendency for each child in the pair to simultaneously conduct the tours individually.

\section{Tours of the outdoor area}

The fourth visit involved tours of the outdoors. In pairs, children led me on a tour, showing and photographing the 'important/interesting/special places.' As well as recording the tour with photographs, our conversation was audio-recorded. As with the findings of other researchers (Clark \& Moss, 2001; Einarsdottir, 2005; Stephenson, 2009), these conversations were particularly rich data.

Tours were conducted at breakneck speed. It was quite a challenge for me to keep up as we gallivanted from one end of the outdoor area and back again, traversing raised platforms, slides, sandpits, and cubbies. In one of her publications, Clark (2010, p. 55) advises keeping a rough map of the tour as it unfolds; I found this to be very useful for later crosschecking of the audio-recordings and the photos that the children had taken.

Figure 4 Example of rough map of child-led tour

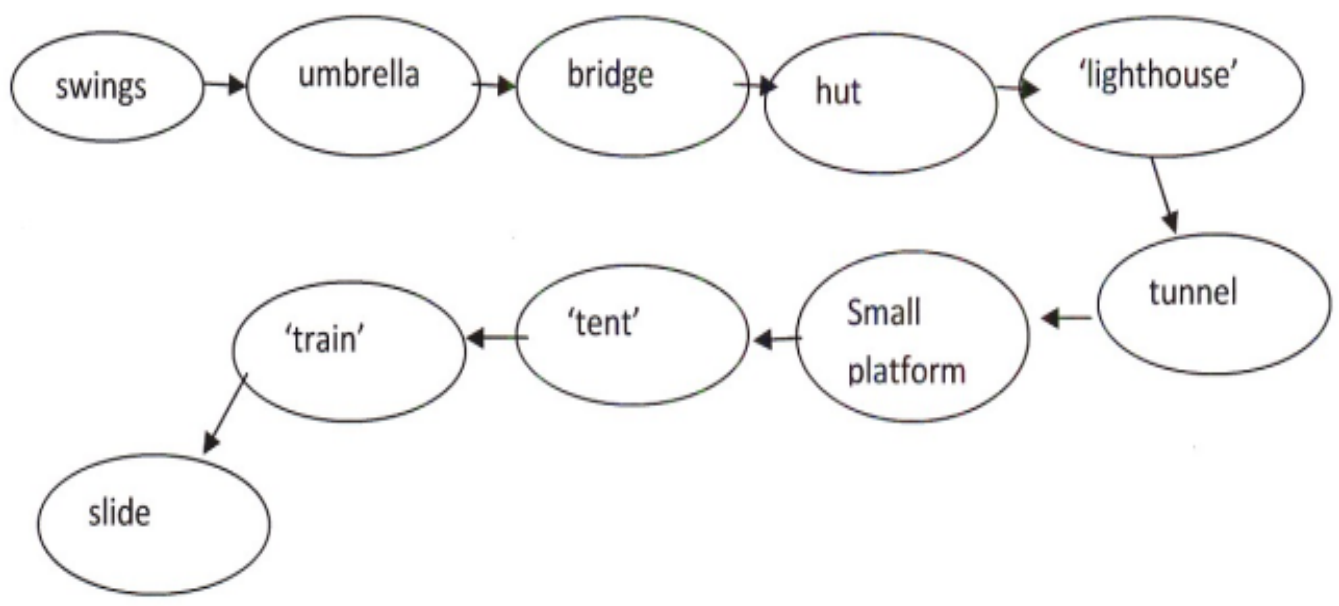

\section{The potential for things to go awry}

Research of this nature is complex and unlikely to go exactly to plan. While there were no major problems, our study's mishaps occurred during the tours, involving either the cameras or the audio recorders. One child dropped her camera in the sand and although it remained 
operational, produced a series of photos framed by a partially opened, jammed shutter. The camera's functionality could later be restored, however, this highlights the possibility of losing expensive equipment in similar research. On another tour I overlooked turning on one child's audio-recorder but because the tours were conducted in pairs, with each child having his or her own audio-recorder, the other child's recorder picked up most of the conversation so I was able to transcribe most of what he said. Therefore, we recommend having two recorders on each tour, enabling crosschecking if one child's voice is less clear. Another tour mishap occurred when I discovered after the event that despite the fact one child had appeared to be taking photos - the camera seemed to be making all the right sounds inexplicably there were no photos on her camera. On my next visit, I explained what had happened and the child, with her partner in tow, enthusiastically re-conducted the tour. My

rough maps revealed that although she conducted the second tour in a slightly different order, she included the same sites as previously.

In spite of these hiccups, ultimately the tours were found to be a very effective method for generating rich data. They were popular with the children, who participated in them with great enthusiasm, having a means of communicating according to their own preferences and strengths. For example, one child took only seven photos but spoke a great deal, while another child, for whom English was not a first language, took 100 photos but spoke very little.

\section{Photo elicitation interviews}

Einarsdottir (2007) advises that indirect, conversational approaches to interviews with young children are preferable to more structured approaches, although Dockett and Perry (2005) note that conversations with children have a tendency to move away from the researchers' goals. Therefore, following the tours, I returned to conduct photo-elicitation interviews (Epstein, Stevens, McKeever, \& Baruchel, 2006; Harper, 2002) with the pairs of children, using their photos as a focus for conversation. The children were very excited to see their own photos printed out and all reacted animatedly to photos they had taken of their friends. Using prompting questions such as, 'What can you tell me about this photo?' and, 'What is interesting/special/important here?' provoked further conversation. Following these conversations, children were asked to place a sticker on 'three photos of the most important places' and these were glued into the documentation book (figure 5). 
Figure 5 Page from documentation book

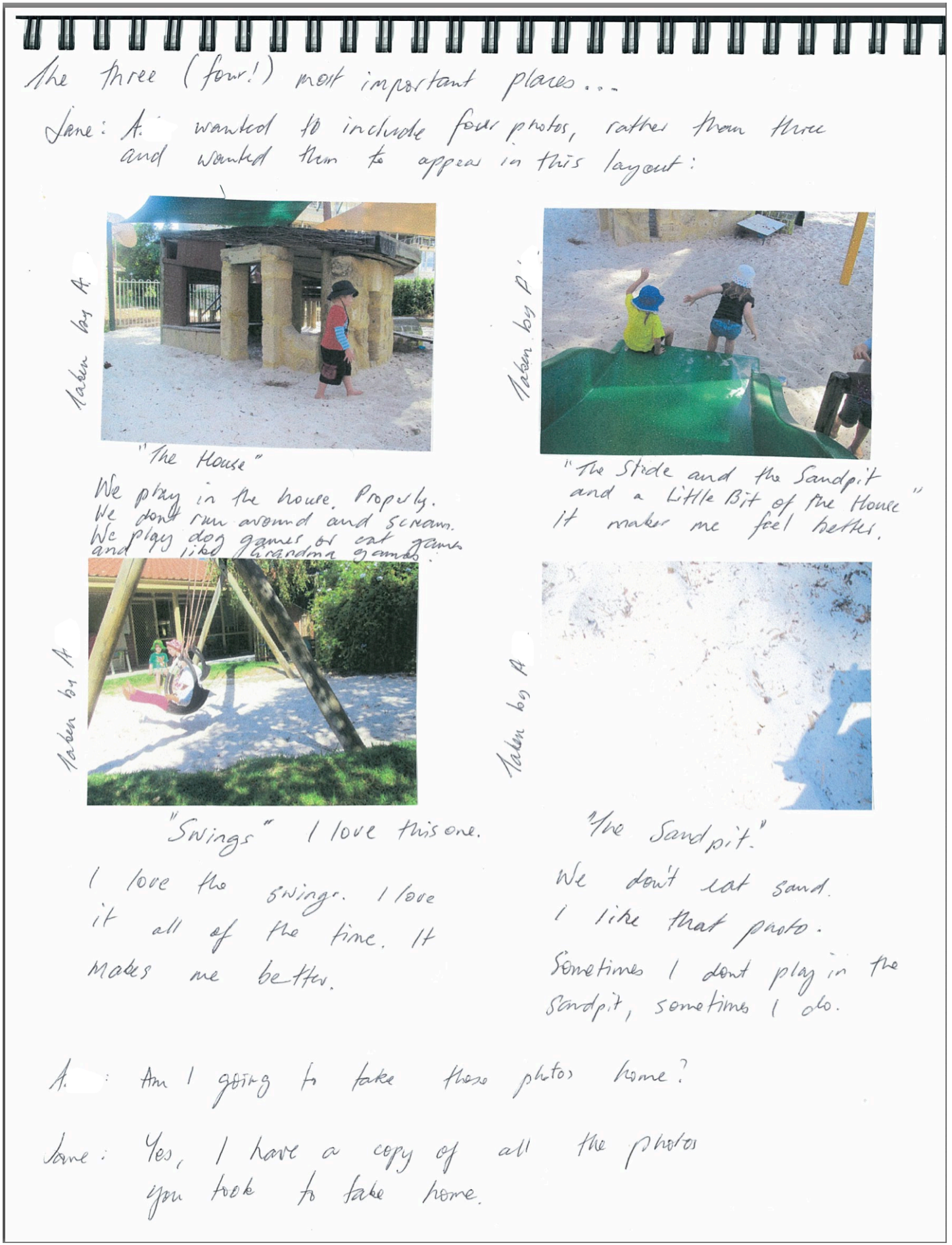

The conversations elicited by this strategy were invaluable. The photos on their own told a partial story but the children's conversations added another rich layer of insights. For example, one child's photo of the sandpit provoked a lengthy description of an imaginary 
game she and a friend often played in this area; another child's photo of a raised platform revealed its importance as a vantage point.

\section{Interviews}

Whilst research aiming to explore children's perspectives avoids formal interviewing of children, asking children direct questions has been shown to reveal valuable insights (for example, Clark, 2010a; Dockett \& Perry, 2005; Smith, Duncan, \& Marshall, 2005). Certainly, in this study, interviews provided another layer of useful data - another piece of the mosaic.

Clark (2010a) notes interview questions that begin with 'tell me about...' can reveal detailed observations, whereas children may refuse to answer questions beginning with 'why'. Therefore, children were invited to tell me about: the best places to go outside; places they do not go; what they like to do outside; where children can play outside; and, what they might and would not change. They were also asked if they had ever used a camera before. With the permission of the children, these interviews were audio-recorded and transcribed.

Interviews with children can be more successful when held in places of children's choosing, or on the move, such as in play (Clark, 2010a). In this study, although some interviews were conducted while children and I were sitting down - at least to begin with, interviews were invariably conducted whilst on the move as children insisted they show me the things they were explaining. Nevertheless, one pair instructed me to stay seated to ask my questions, assuring me that they would answer a few and then 'go off for a play' and return later to answer more questions. I complied with their request and they stuck to their end of the bargain without any further encouragement from me.

\section{The slide show: focusing conversations}

This layer of data, or mosaic piece, is another example of photo-elicitation interviewing (Epstein et al., 2006; Harper, 2002). This strategy was inspired by Clark's 'magic carpet' (Clark, 2005, pp. 43-45) whereby she showed children a slide show of adult-taken photos of a variety of outdoor environments, including the setting being studied. In our study, as a way of providing an opportunity to revisit photos taken by the children, we included the three photos each child had identified as the most important/interesting places, along with images we had chosen to see what reactions they provoked from the children. Adult-selected images included photos of the children's garden at Melbourne Botanical Garden. Also, because these children had frequently talked about climbing, being 'up' and 'high', and referred to two 
outdoor structures as 'lighthouses', our slide show included a photo of a real lighthouse, as well as a spiral-shaped ramp built around a tree at Tokyo's Fuji Kindergarten (http://www.tezuka-arch.com/japanese/works/ring/06.html), and two photos of tower-like playground structures designed by Danish landscape architect Helle Nebelong (http://www.sansehaver.dk/asp/side/english.html). Photos of modular playground equipment were also included.

Due to weather constraints, the slide show was projected in the doorway of a storage shed that opened onto the outdoor area. Unfortunately, as children were not usually permitted to enter this space, it proved to be somewhat distracting. The original intention of presenting the slide show to pairs of children was not achievable as the shed attracted many other children. The resulting ruckus meant that the recorded conversations could not be transcribed.

Nonetheless, the slide show provided some useful data, though more limited than expected. We believe, however, that this strategy has potential; in future studies further attention should be given to ensuring an appropriate setting to enable children's voices to be heard.

\section{Extending means of representation: drawing}

In research, children's drawings have been used for exploring their perspectives (Clark, 2010a; Einarsdottir, Dockett, \& Perry, 2009; Wright, 2007). As drawing provides children with another language (Edwards et al., 2012b) for expressing ideas, following the slide show, children were invited to draw what they liked about the centre's outdoor environment, or those they had experienced elsewhere. Like photography, drawing gives children the option of non-verbal expression allowing them to be active and creative. Einarsdottir (2007) advises, however, that it is important to include observations of children's narratives and interpretations as they draw, rather than trying to interpret what they have drawn out of context; advice we heeded in our study.

Drawing was certainly familiar to these children. Not only was there a designated drawing area indoors, but there was also a drawing area outside. Despite this, few children were keen to draw their ideas about outdoor environments. Three children responded by saying, 'I can't draw', and while two children agreed to draw, they showed little enthusiasm after beginning. Their lack of enthusiasm and furtive looks to their peers who were playing elsewhere was taken as a withdrawal of assent, and this was confirmed when they left the activity as soon as they were reminded that their participation was optional. But for the 
children who were confident with it, drawing was eagerly approached, and for one child it was a particularly attractive activity and focus for our conversation.

\section{Reflections}

The challenge of our study was to find ways to seek young children's perspectives about outdoor spaces in their pedagogical setting. No single strategy used stood out as being 'best'. Like Clark and Moss (2001), we found using a range of strategies effective as they not only allowed for triangulation of data, but also for children's interests and strengths. Drawing, for example, was rejected by a number of children in our study, but for one it was a powerful tool. The tour strategy, with its combination of photography and conversation, appealed greatly to children, providing many insights, but the other strategies furthered these insights. Informal conversation was pivotal to all of the strategies, but these conversations were enhanced when children had something purposeful to do whilst they were talking.

But it was not just the layering of strategies that was valuable in this study. Highly significant were the affordances the multimodal strategies provided for adult-children interactions, children-children interactions, and the possibility to make these visible. These strategies did not relegate the researcher to 'fly on the wall', nor did they relegate children to being voiceless objects of research. Rather, they provided a catalyst for dialogue amongst children and adults and thus developed relationships and the ability to communicate with each other, in a variety of ways.

A developmental paradigm may not have supported such a project as it may have engendered an assumption that these children were not yet competent (Woodhead \& Faulkner, 2008). Instead, by taking a view of children as having 'extraordinary strengths and capabilities, linked with an inexhaustible need for expression' (Malaguzzi, cited in Gandini, 2012, p. 53) and by choosing methods which provided a 'discursive space for differing perspectives and forms of expression, where there is room for dialogue, confrontation (in the sense of exchanging differing experience and views), deliberation and critical thinking, where children and others can speak and be heard' (Dahlberg \& Moss, 2005, p. 29), we found children to be reliable, knowledgeable, and trustworthy informants, able to convey a clear picture of what was important to them in this outdoor space.

\section{A cautionary note}

It is possible that consultation is undertaken and then ignored. Clark and Percy-Smith (2006, p. 3) point out, 'Participation can be turned into another managerial process in order to tick 
boxes and meet targets according to policy priorities.' This, in our view, would be deeply disrespectful and would be worse than not seeking children's views at all. We suggest that for similar studies, to avoid the possibility of children being consulted for tokenistic purposes, a further step is included evaluating the results of children's participation.

\section{Limitations}

Such an approach is not without limitations. This small study focused on eight children in one setting. In a different context researchers will need to assess if the approaches taken in this instance will be suitable. Further, this was not a speedy way to investigate; as well as time spent at the setting, large amounts of data were generated that were time-consuming to analyse. The methods used required cameras, audio-recorders and other materials that had to be sourced and paid for. Finally, this research required skills in dialoguing with children, pedagogical approaches, and documenting children's thinking. Mac Naughton, Hughes and Smith (Mac Naughton et al., 2007) suggest a lack of expertise in working with young children could be a reason why children's perspectives are not being heard in the public sphere. Our experiences in this project lead us to agree.

\section{Conclusion}

Finding ways to enable children to be heard continues to be a challenge (Ailwood et al., 2011; Pascal \& Bertram, 2009). This paper has described methods used in one study to seek children's perspectives. The methods are productive pedagogical techniques inspired by the educational project of Reggio Emilia that also present possibilities for respectful research. One strategy alone was not sufficient; a combination of strategies that offered possibilities for children and adults to work together was found to provide children with the most opportunities to express themselves. It is our view that as researchers and educators, we have a responsibility to strive to find ways that children can enjoy the rights articulated in the United Nations Convention on the Rights of the Child (United Nations, 1989), including the right to be involved in decisions that affect them. This is a conversation that is still in its infancy; we hope that our study contributes to this ongoing exchange.

\section{Acknowledgements}

We are very grateful to the early childhood centre that participated in this study - thank you to the families, educators, and most importantly, the children. 


\section{References}

Agbenyega, J. (2011). Researching children's understanding of safety: An auto-driven visual approach. Contemporary Issues in Early Childhood, 12(2), 163-174.

Ailwood, J., Brownlee, J., Johansson, E., Cobb-Moore, C., Walker, S., \& Boulton-Lewis, G. (2011). Educational policy for citizenship in the early years in Australia. Journal of Education Policy, 26(5), 641-653. doi: 10.1080/02680939.2011.587538

Anning, A., \& Edwards, A. (2006). Promoting children's learning from birth to five: Developing the new early years professional. Berkshire: Open University Press.

Australian Government Department of Education Employment and Workplace Relations (AGDEEWR). (2009). Belonging, being and becoming: The early years learning framework for Australia. Retrieved from http://docs.education.gov.au/system/files/doc/other/belonging_being_and_bec oming_the_early_years_learning_framework_for_australia.pdf.

Bruner, J. (1996). The culture of education. Cambridge, MA: Harvard University Press.

Clark, A. (2005). Ways of seeing: Using the Mosaic approach to listen to young children. In A. Clark, A. Kjorholt \& P. Moss (Eds.), Beyond listening: Children's perspectives on early childhood services (pp. 29-50). Bristol, UK: The Policy Press.

Clark, A. (2010a). Transforming children's spaces: Children's and adults' participation in designing learning environments. London: Routledge.

Clark, A. (2010b). Young children as protagonists and the role of participatory, visual methods in engaging multiple perspectives. American Journal of Community Psychology, 46(1-2), 115-123. doi: 10.1007/s10464-010-9332-y

Clark, A., \& Moss, P. (2001). Listening to young children: The Mosaic approach. London: National Children's Bureau.

Clark, A., \& Moss, P. (2005). Spaces to play: More listening to young children using the Mosaic approach. London: National Children's Bureau.

Clark, A., \& Percy-Smith, B. (2006). Beyond consultation: Participatory practices in everyday spaces. Children, Youth and Environments, 16(2), 1-9.

Conroy, H., \& Harcourt, D. (2009). Informed agreement to participate: Beginning the partnership with children in research. Early Child Development and Care, 179(2), 157-165.

Corsaro, W. A. (1997). The sociology of childhood. Thousand Oaks, CA: Pine Forge Press.

Dahlberg, G., \& Moss, P. (2005). Ethics and politics in early childhood education. London \& New York: RoutledgeFalmer.

Dahlberg, G., Moss, P., \& Pence, A. (2007). Beyond quality in early childhood education and care: Languages of evaluation (2nd ed.). London: Routledge.

Dockett, S., \& Perry, B. (2005). Researching with children: Insights from the Starting School Research Project. Early Child Development and Care, 175(6), 507 - 521.

Dockett, S., Perry, B., \& Kearney, E. (2012). Promoting children's informed assent in research participation. International Journal of Qualitative Studies in Education, 1-27. doi: 10.1080/09518398.2012.666289

Edwards, C., Gandini, L., \& Forman, G. (2012a). Introduction. In C. Edwards, L. Gandini \& G. Forman (Eds.), The hundred languages of children: The Reggio Emilia experience in transformation (3rd ed., pp. 5-26). Santa Barbara: CA: Praeger.

Edwards, C., Gandini, L., \& Forman, G. (Eds.). (2012b). The hundred languages of children: The Reggio Emilia experience in transformation (3rd ed.). Santa Barbara: CA: Praeger. 
Einarsdottir, J. (2005). Playschool in pictures: Children's photographs as a research method. Early Child Development and Care, 17(6), 523-541. doi: 10.1080/03004430500131320

Einarsdottir, J. (2007). Research with children: Methodological and ethical challenges. European Early Childhood Education Research Journal, 15(2), 197-211. doi: 10.1080/13502930701321477

Einarsdottir, J., Dockett, S., \& Perry, B. (2009). Making meaning: children's perspectives expressed through drawings. Early Child Development and Care, 179(2), 217232.

Epstein, I., Stevens, B., McKeever, P., \& Baruchel, S. (2006). Photo elicitation interview (PEI): Using photos to elicit children's perspectives. International Journal of Qualitative Methods, 5(3), 1-11.

Fleet, A., \& Britt, C. (2011). Seeing spaces, inhabiting places: Hearing school beginners. In D. Harcourt, B. Perry \& T. Waller (Eds.), Researching young children's perspectives: Debating the ethics and dilemmas of educational research with children (pp. 143-162). London \& New York: Routledge.

Fleet, A., Patterson, C., \& Robertson, J. (Eds.). (2006). Insights: Behind pedagogical documentation. Castle Hill, NSW: Pademelon Press.

Fleet, A., Patterson, C., \& Robertson, J. (Eds.). (2012). Conversations: Behind early childhood pedagogical documentation. Mt Victoria, NSW: Pademelon Press.

Foucault, M. (1987). The ethic of care for the self as a practice of freedom. In J. Bernauer \& D. Rasmussen (Eds.), The final Foucault (pp. 1-20). Cambridge, MA: MIT Press.

Gallacher, L., \& Gallagher, M. (2008). Methodological immaturity in childhood research? Thinking through 'participatory methods'. Childhood, 15(4), 499-516.

Gandini, L. (2012). History, ideas, and basic principles: An interview with Loris Malaguzzi. In C. Edwards, L. Gandini \& G. Forman (Eds.), The hundred languages of children: The Reggio Emilia experience in transformation (pp. 27-71). Santa Barbara: Praeger.

Giudici, C., Rinaldi, C., \& Krechevsky, M. (Eds.). (2001). Making learning visible: Children as individual and group learners. Reggio Emilia, Italy: Reggio Children.

Harcourt, D. (2011). An encounter with children: Seeking meaning and understanding about childhood. European Early Childhood Education Research Journal, 19(3), 331-343. doi: 10.1080/1350293x.2011.597965

Harcourt, D., \& Conroy, H. (2005). Informed assent: Ethics and processes when researching with young children. Early Child Development and Care, 175(6), 567577. doi: 10.1080/03004430500131353

Harcourt, D., \& Conroy, H. (2011). Informed consent: Processes and procedures in seeking research partnerships with young children. In D. Harcourt, B. Perry \& T. Waller (Eds.), Researching young children's perspectives: Debating the ethics and dilemmas of educational research with children (pp. 38-51). London \& New York: Routledge.

Harper, D. (2002). Talking about pictures: A case for photo elicitation. Visual Studies, 17(1), 13-26. doi: 10.1080/14725860220137345

James, A., Jenks, C., \& Prout, A. (1998). Theorising childhood. Cambridge: Polity Press. James, A., \& Prout, A. (Eds.). (1990). Constructing and reconstructing childhood. London: Falmer.

Lander, F., Tennant, J., \& Webb, J. (Eds.). (2005). Caterpillar toothpaste: A child's introduction to the decision making process. West Perth, WA: Office for Children and Youth. 
Lansdown, G. (2005). Can you hear me? The right of young children to participate in decisions affecting them. The Hague: Bernard van Leer Foundation.

LeCompte, M. D., Preissle, J., \& Tesch, R. (1993). Ethnography and qualitative design in educational research (2nd ed.). San Diego, CA: Academic Press.

Lenz Taguchi, H. (2009). Going beyond the theory/practice divide in early childhood education: Introducing an intra-active pedagogy. New York: Routledge.

Loizou, E. (2011). Disposable cameras, humour and children's abilities. Contemporary Issues in Early Childhood, 12(2), 148-162.

Mac Naughton, G., Hughes, P., \& Smith, K. (2007). Early childhood professionals and children's rights: tensions and possibilities around the United Nations General Comment No. 7 on Children's Rights. International Journal of Early Years Education, 15(2), 161-170. doi: 10.1080/09669760701288716

Mayall, B. (2002). Towards a sociology for childhood: Thinking from children's lives. Buckingham: Open University Press.

Merewether, J. (2007a). About face. The Challenge Journal of Reggio Emilia Australia Information Exchange, 10(4), 4-9.

Merewether, J. (2007b). Research through debate and discussion. The Challenge Journal of Reggio Emilia Australia Information Exchange, 10(4), 18-19.

Merewether, J. (2012). The outdoors as a pedagogical space: Children's perspectives. (Unpublished Master of Early Childhood dissertation), Macquarie University, Sydney.

Merriam, S. (1998). Qualitative research and case study applications in education. San Francisco, CA: Jossey-Bass.

Merriam, S. (2009). Qualitative research: A guide to design and implementation. San Francisco, CA: Jossey-Bass.

National Childcare Accreditation Council Inc. (2005). Factsheet 2: Involving children in decision making, from http://www.ncac.gov.au/child_care

Pascal, C., \& Bertram, T. (2009). Listening to young citizens: the struggle to make real a participatory paradigm in research with young children. European Early Childhood Education Research Journal, 17(2), 249-262. doi: 10.1080/13502930902951486

Qvortrup, J., Corsaro, W. A., \& Honig, M.-S. (Eds.). (2009). The Palgrave handbook of childhood studies. Basingstoke, UK: Palgrave Macmillan.

Rinaldi, C. (2006). In dialogue with Reggio Emilia: Listening, researching and learning. London: Routledge.

Rogoff, B. (2003). The cultural nature of human development. New York: Oxford University Press.

Smith, A. (2011). Respecting children's rights and agency: Theoretical insights into ethical research procedures. In D. Harcourt, B. Perry \& T. Waller (Eds.), Researching young children's perspectives: Debating the ethics and dilemmas of educational research with children (pp. 11-25). London \& New York: Routledge.

Smith, A., Duncan, J., \& Marshall, K. (2005). Children's perspectives on their learning: Exploring methods. Early Child Development and Care, 175(6), 473-487.

Smith, A., \& Taylor, N. (2000). Introduction. In A. Smith, N. Taylor \& M. Gollop (Eds.), Children's voices: Research, policy and practice (pp. ix-xiii). Auckland: Pearson Education New Zealand.

Stephenson, A. (2009). Horses in the sandpit: Photography, prolonged involvement and 'stepping back' as strategies for listening to children's voices. Early Child Development and Care, 179(2), 131-141. 
United Nations. (1989). The United Nations Convention on the Rights of the Child. New York: UNICEF.

United Nations. (2005). Convention on the Rights of the Child General Comment No. 7. Retrieved from http://www2.ohchr.org/english/bodies/crc/docs/AdvanceVersions/GeneralCo mment7Rev1.pdf

Vecchi, V. (2010). Art and creativity in Reggio Emilia: Exploring the role and potential of ateliers in early childhood education. London: Routledge.

Vygotsky, L. S. (1978). Mind in society. Cambridge, MA: Harvard University Press.

Woodhead, M., \& Faulkner, D. (2008). Subjects, objects or participants? Dilemmas of psychological research with children. In P. Christensen \& A. James (Eds.), Research with children: Perspectives and practices (2nd ed., pp. 10-39). London: Falmer.

Wright, S. (2007). Young children's meaning-making through drawing and 'telling': Analogies to filmic textual features. Australian Journal of Early Childhood, 32(4), 37-48. 